\title{
Two Triterpenoid Saponins with a-glucosidase Inhibitory Activity from Harpullia pendula Seed Extract
}

\author{
Marian Nabil, Neveen S. Ghaly, Iman A.A. Kassem, Mary H. Grace and Farouk R. Melek*
}

Marian Nabil, Neveen S. Ghaly, Iman A.A. Kassem, Mary H. Grace and Farouk R. Melek*

Chemistry of Natural Compounds Department, National Research Centre, Dokki,12622, Giza, EGYPT.

\section{Correspondence}

Farouk R. Melek

Chemistry of Natural Compounds

Department National Research Centre

Dokki, 12622, Giza, EGYPT.

E-mail: frmelek1@gmail.com

History

- Submission Date: 20-06-2019;

- Review completed: 08-07-2019;

- Accepted Date: 30-07-2019.

DOI : 10.5530/pj.2019.11.214

Article Available online

http://www.phcogj.com/v11/i6s

Copyright

() 2019 Phcogj.Com. This is an openaccess article distributed under the terms of the Creative Commons Attribution 4.0 International license.

\section{ABSTRACT}

Background: Harpullia pendula Planch (family Sapindaceae) is a small to medium rainforest tree native to Australia. Objective: This study aims to isolate triterpenoid saponins from $\mathrm{H}$. pendula and test them as a-glucosidase inhibitors. Materials and Methods: The saponin compounds were obtained using variable chromatographic techniques and characterized by spectral analysis. Results: Two new triterpenoid saponins were obtained as an inseparable mixture from $H$. pendula methanolic seed extract. Their structures were determined as 3-O- $\beta$-D-glucopyranosyl- $(1 \rightarrow 2)$-[ $\alpha$-L-arabinofuranosyl-(1 $\rightarrow 3)$ ]- $\beta D$-glucuronopyranosyl22-O angeloyIA1-barrigenol and 3-O- $\beta$-D-galactopyranosyl- $(1 \rightarrow 2)$-[ $\alpha$-L-arabinofuranosyl-( $1 \rightarrow 3)$ - $\beta$-Dglucuronopyranosyl 22-O-(2-methylbutyroyl)-A1 barrigenol, respectively. The triterpene part 22-O-(2-methyl butyroyl) A1-barrigenol has never been characterized before. The $\alpha$ - glucosidase inhibitory activity of the two saponin mixture was evaluated invitro and proved to exhibit strong activity with $I C_{50}$ value equals to $13.3 \pm 5.0 \mathrm{ppm}$ and $\mathrm{IC}_{90}$ value equals to $21.5 \pm 8.0 \mathrm{ppm}$. Conclusion: Two new saponins were characterized from their mixture and found to exhibit $\alpha$-glucosidase inhibitory activity.

Key words: Harpullia pendula, Sapindaceae, Triterpenoid saponins.

\section{INTRODUCTION}

The plants of genus Harpullia (family Sapindaceae) are widely distributed from Malesia and Australia to the Pacific islands. ${ }^{1}$ Previous investigations carried out on these plants proved them to be rich in polyhydroxylated triterpenoid saponins..$^{2-5}$ This type of saponins was reported to exhibit antimicrobial, ${ }^{6-8}$ molluscicidal, miracidicidal and cercaricidal activities ${ }^{9}$ as well as cytotoxic and Haemolytic properties. ${ }^{4}$

Harpullia pendula Planch known as tulipwood or tuliplance wood is a small to medium rainforest tree native to Australia. Phytochemical studies carried out on this species resulted in the isolation and characterization of the triterpenes A1-barrigenol, A1-barrigenol-22$\mathrm{O}$-angelate, camelliagenin A, camelliagenin-16 and 22-O-angelate, 22-a-hydroxyerthrodiol and $15 \alpha, 16 \alpha, 22 \alpha, 28$-tetrahydroxy-12-ene-3-one as well as quebrachitol and methyl- $p$-coumarate. ${ }^{10,11}$ Three sapogenins characterized as angeloyl camelliagenin A, angeloyl A1- barrigenol and angeloyl A1barrigenolmethyl ether, were also described from $H$. pendula and $H$. cupanioides. ${ }^{12}$ Several acylated triterpenoid saponins with variable ester functions and sugar chains, were isolated and characterized from $H$. cupanioides, ${ }^{2} H$. austro-caledonica, ${ }^{3}$ and $H$. pendula. ${ }^{5}$ Flavonoids and phenolics from $H$. pendula were also reported. ${ }^{5,13}$ Furthermore, two antimicrobial benzene acetic acid derivatives together with kaempferol glycosides were reported from $H$. pendula. ${ }^{14}$

As a part of our continuous investigations on bioactive saponins from plants cultivated in Egypt, ${ }^{5}$ we described in this report the characterization of two further saponins from $H$. pendula.

\section{RESULTS AND DISCUSSION}

The butanol fraction from the defatted methanolic seed extract of $H$. pendula, was subjected to the polymer gel Diaion HP-20 and silica gel column chromatography to afford eight fractions. Previous examination of the major fraction by us, led to the isolation and characterization of the two saponins pendulaosides A and B. ${ }^{5}$ In this report we described the characterization of two further new saponins 1 and 2 obtained as inseparable mixture from $H$. pendula. The negative high resolution LCESI-TOF-MS spectrum of $\mathbf{1}$ and $\mathbf{2}$ revealed the presence of two molecular ion peaks $[\mathrm{M}-\mathrm{H}]^{-}$at $m / z$ 1041-5229 $\left(\mathrm{C}_{52} \mathrm{H}_{81} \mathrm{O}_{21}\right)$ and at $m / z 1043.5415$ $\left(\mathrm{C}_{52} \mathrm{H}_{83} \mathrm{O}_{21}\right)$, respectively. The ${ }^{1} \mathrm{H}-\mathrm{NMR}(700 \mathrm{MHz})$ and ${ }^{13} \mathrm{C}$-NMR $(175 \mathrm{MHz})$ spectra of $\mathbf{1}$ and $\mathbf{2}$ showed a set of major signals due to the common parts of the two molecules and minor ones corresponding to the other moieties with higher intensity for those of 1 . The ${ }^{1} \mathrm{H}-\mathrm{NMR}$ spectrum (Table 1 ) showed the presence of seven methyl singlets at $\delta_{\mathrm{H}} 1.40,1.08$, $1.05,1.03,0.99,0.91$ and $0.88 \mathrm{ppm}$, four oxymethine proton signals at $\delta_{\mathrm{H}} 3.21(d d, J=12.0,4.0 \mathrm{~Hz}), 3.77$ $(m), 3.92(d, J=4.5 \mathrm{~Hz})$ and $5.45(d d, J=14.0,6.3 \mathrm{~Hz})$ together with oxymethylene proton signals at $\delta_{\mathrm{H}} 3.31$ $(d, J=11.0 \mathrm{~Hz})$ and $3.13(d, J=11.0 \mathrm{~Hz})$. The spectrum also revealed the presence of an olefinic proton signal at $\delta_{\mathrm{H}} 5.43(\mathrm{brt}, J=3.0 \mathrm{~Hz})$. These data suggested the presence of a triterpene moiety of oleanene skeleton. Extensive $1 \mathrm{D}\left({ }^{1} \mathrm{H},{ }^{13} \mathrm{C}\right)$ and $2 \mathrm{D}\left({ }^{1} \mathrm{H}-{ }^{1} \mathrm{H}\right.$ COSY, TOCSY, HMQC, HMBC) NMR analysis, allowed complete assignments of the proton and carbon signals of a common triterpene part for $\mathbf{1}$ and $\mathbf{2}$ and confirmed

Cite this article: Nabil M, Ghaly NS, Kassem IAA, Grace MH, Melek FR. Two Triterpenoid Saponins with $\alpha$-glucosidase Inhibitory Activity from Harpullia pendula Seed Extract. Pharmacog J. 2019;11(6)Suppl:1386-90. 
Table 1: ${ }^{1} \mathrm{H}$ and ${ }^{13} \mathrm{CNMR}$ data of compounds 1 and 2 in $\mathrm{CD}_{3} \mathrm{OD}$.

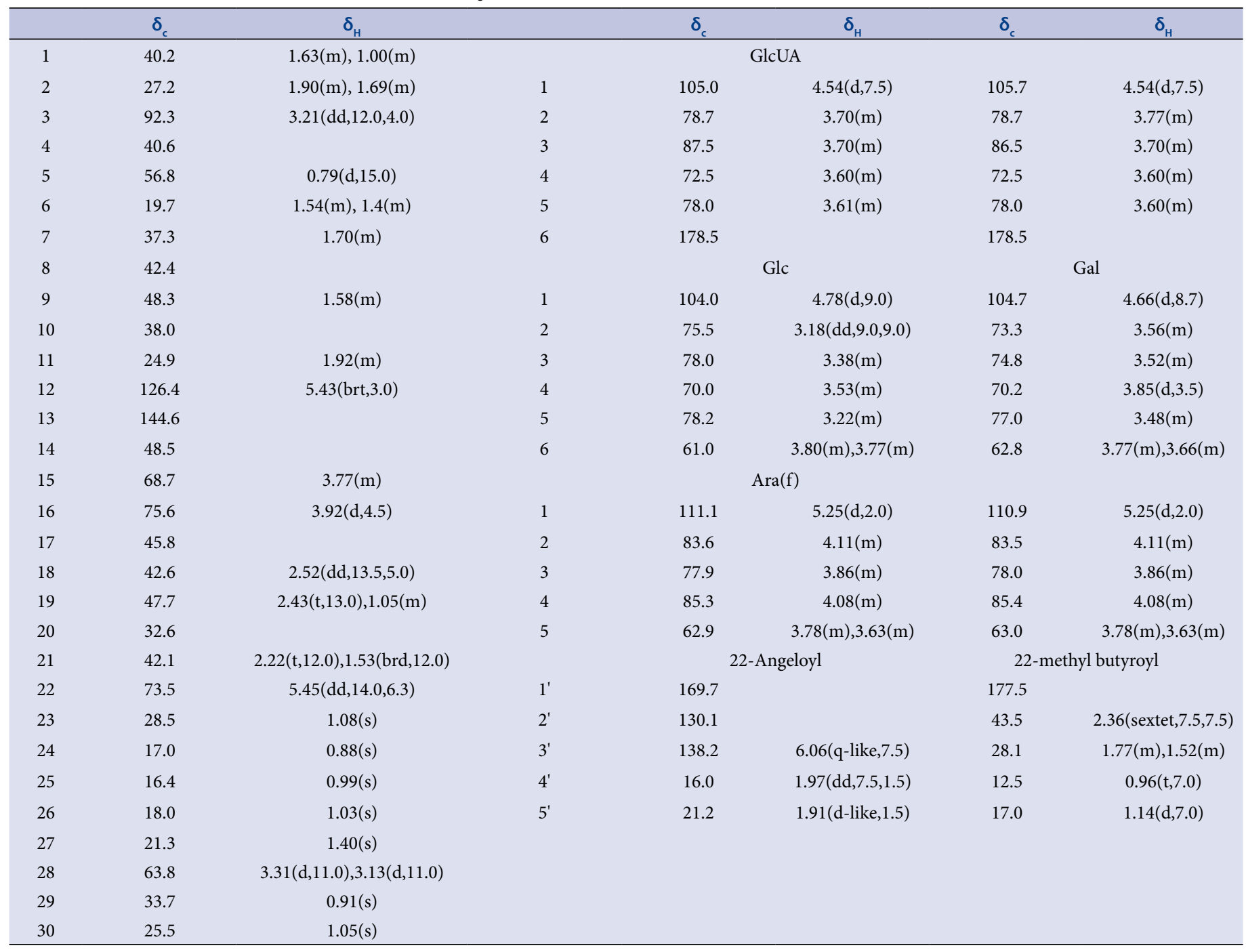

the existence of the five oxygenated carbons in this triterpene moiety. The proton signal at $\delta_{\mathrm{H}} 3.21$ correlated with a carbon signal at $\delta_{\mathrm{C}} 92.3$ in the HMQC spectrum and with C-23 $\left(\delta_{C} 28.5\right)$ and C-24 $\left(\delta_{C} 17.0\right)$ signals in the HMBC spectrum, was assigned to the $\mathrm{H}-3 \alpha$. The proton signal at $\delta_{\mathrm{H}} 3.77$ was assigned to $\mathrm{H}-15 \beta$ based on direct correlation with carbon signal at $\delta_{\mathrm{C}} 68.7$ in the HMQC spectrum and coupling to $\mathrm{H}-16$ signal $\left(\delta_{\mathrm{H}} 3.92, d, J=4.5 \mathrm{~Hz}\right)$ in the ${ }^{1} \mathrm{H}-{ }^{1} \mathrm{H}$ COSY and TOCSY experiments as well as $\mathrm{HMBC}$ correlations between 27-methyl signal at $\delta_{\mathrm{H}} 1.40$ and $\mathrm{C}-15$ signal at $\delta_{\mathrm{C}} 68.7$. The proton signal at $\delta_{\mathrm{H}} 3.92(d, J=4.5 \mathrm{~Hz})$ coupled to $\mathrm{H}-15$ signal in the COSY and TOCSY and directly correlated with a carbon signal at $\delta_{\mathrm{C}} 75.6$, was assigned to $\mathrm{H}-16 \beta$. The assignment was confirmed by the HMBC correlations between $\mathrm{H}-16$ signal and signals due to C-15, C-17 $\left(\delta_{\mathrm{C}} 45.8\right)$, and C-18 $\left(\delta_{\mathrm{C}} 42.6\right)$. The deshielded signal at $\delta_{\mathrm{H}} 5.45\left[d d, J=14,6.3, \delta_{\mathrm{C}} 73.5\right]$ was assigned to $\mathrm{H}-22 \beta$ based on coupling constant values and $\mathrm{HMBC}$ correlations with C-16, C-17, C-21 $\left(\delta_{C} 42.1\right)$ and $\mathrm{C}-28\left(\delta_{C} 63.8\right)$. The observed downfield position of $\mathrm{H}-22 \beta$ suggested acylation at this position. The oxymethylene proton signals $\left(\delta_{\mathrm{H}} 3.31,3.13\right)$ appeared in $\mathrm{the}^{1} \mathrm{H}-{ }^{1} \mathrm{H}$ COSY spectrum as an isolated $\mathrm{AB}$ system, were assigned to $\mathrm{H}_{2}-28$ based on HMBC correlations with $\mathrm{C}-17$ and C-18 signals. The olefinic proton signal at $\delta_{\mathrm{H}} 5.43$ was assigned to $\mathrm{H}-12$ on the basis of direct correlation with carbon signal at $\delta_{\mathrm{C}} 126.4$ and coupling to $\mathrm{H}_{2}-11$ signal at $\delta_{\mathrm{H}} 1.92$ in the ${ }^{1} \mathrm{H}-{ }^{1} \mathrm{H}$ COSY spectrum. Based on the above information and comparison with literature data, both $\mathbf{1}$ and $\mathbf{2}$ had a triterpene part assigned as A1-barrigenol acylated at C-22 position. The $1 \mathrm{D}$ and $2 \mathrm{D}$ NMR analysis also revealed the presence of one set of signals due to an angeloyl residue and another set of lower intensity corresponding to a 2-methylbutyroyl group. The characteristic signals of the angeloyl residue were $\delta_{\mathrm{H}} 6.06\left[\left(1 \mathrm{H}, q\right.\right.$-like, $\left.J=7.5 \mathrm{~Hz}, \mathrm{H}-3^{\prime}\right)$, $\left.\delta_{\mathrm{C}} 138.2\right], 1.97\left[\left(3 \mathrm{H}, d d, J=7.5,1.5, \mathrm{H}-4^{\prime}\right), \delta_{\mathrm{C}} 16.0\right], 1.91[(3 \mathrm{H}, d$-like, $J=1.5$ $\left.\left.\mathrm{Hz}, \mathrm{H}-5^{\prime}\right), \delta_{\mathrm{C}} 21.1\right]$ along with signals at $\delta_{\mathrm{C}} 169.7$ (C-1 '), and $130.1(\mathrm{C}-$ 2 '). These data were very similar to the corresponding ones reported for other structurally related saponins bearing an angelate moiety. ${ }^{2,5,15,16}$ The characteristic signals of the 2-methylbutyroyl group were $\delta_{\mathrm{H}} 2.36[(1 \mathrm{H}$, sextet, $\left.\left.J=7.5,7.5 \mathrm{~Hz}, \mathrm{H}-2^{\prime}\right), \delta_{\mathrm{C}} 43.5\right], 1.52$ and 1.77 (each $\left.1 \mathrm{H}, m, \mathrm{H}-3^{\prime}\right)$, $\left.\delta_{c} 28.1\right], 0.96\left[3 \mathrm{H}, t, J=7.0 \mathrm{~Hz}, \mathrm{H}-4^{\prime}, \delta_{\mathrm{C}} 12.5\right]$ and $1.14[(3 \mathrm{H}, d, J=7 \mathrm{~Hz}$, $\left.\left.\mathrm{H}-5^{\prime}\right), \delta_{\mathrm{C}} 17.0\right]$ together with $\delta_{\mathrm{C}} 177.5$ (C-1 $\left.{ }^{\prime}\right){ }^{5}$ The two ester moieties showed identical HMBC correlations to those previously reported by us for similar saponins bearing the same groups. ${ }^{5}$ The HMBC correlations of the carbonyl carbons of the two ester groups at $\delta_{\mathrm{C}} 169.9$ and 177.5 and the $\mathrm{H}-22 \beta$ proton signal at $\delta_{\mathrm{H}} 5.45$ verified acylation at $\mathrm{C}-22$ position of the $\mathrm{A} 1$ barrigenol moiety. Consequently, the triterpene parts of 1 and 2 were defined as 22-O-angeloyl A1-barrigenol(Tri1) and 22-O-(2-methyl butyroyl) A1-barrigenol(Tri2), respectively. The triterpene part 22-O-(2-methylbutyroyl)-A1-barrigenol[22-O-(2methylbutyroyl) $3 \beta, 15 \alpha, 16 \alpha, 22 \alpha, 28$-pentahydroxyol] has never been characterized before.

Acid hydrolysis of mixture of $\mathbf{1}$ and $\mathbf{2}$ afforded the sugar components $\mathrm{D}$-glucuronic acid, L-arabinose, $\mathrm{D}$-glucose and $\mathrm{D}$-galactose, indicating the glycosidic nature of $\mathbf{1}$ and $\mathbf{2}$. The absolute configurations of these sugars were assigned based on their optical rotation values. The sugar parts of 1 and 2 revealed in the ${ }^{1} \mathrm{H}$ NMR spectrum (Table 1), the 
occurrence of two major anomeric proton signals at $\delta_{\mathrm{H}} 5.25(d, J=2.0$ $\mathrm{Hz})$ and $4.54(d, J=7.5 \mathrm{~Hz})$ as well two minor ones at $\delta_{\mathrm{H}} 4.78(d, J=9.0$ $\mathrm{Hz})$ and $4.66(d, J=8.7 \mathrm{~Hz})$. In the HMQC spectrum the signal at $\delta_{\mathrm{H}} 5.25$ was directly correlated with two anomeric carbon signals at $\delta_{\mathrm{C}} 111.1$ and 110.9 (Table 1 ), while the signal at $\delta_{\mathrm{H}} 4.54$ was correlated with two anomeric carbon signals at $\delta_{\mathrm{C}} 105.7$ and 105.0. The signals at $\delta_{\mathrm{H}} 4.78$ and 4.66 were correlated with anomeric carbon signals at $\delta_{\mathrm{C}} 104.0$ and 104.7, respectively. The combined use of the ${ }^{1} \mathrm{H}-{ }^{1} \mathrm{H}$ COSY and TOCSY spectra allowed the sequential assignments of the proton signals of all sugar units. Based on the assigned protons, the carbon signals of each monosaccharide were identified by the use of HMQC spectrum. Unambiguous assignments of closely related protons and carbons were made possible by the aid of HMBC experiment. The sugar with the anomeric proton signal at $\delta_{\mathrm{H}} 4.54$ was assigned to a 2,3-disubstituted $\beta$-D-glucuronopyranosyl unit (GlcUA) while the proton signal at $\delta_{\mathrm{H}} 5.25$ was assigned to a terminal $\alpha$-L-arabinofuranosyl unit (Ara(f)). The two anomeric proton signals at $\delta_{\mathrm{H}} 4.78$ and 4.66 were assigned to a $\beta$-D-glucopyranosyl (Glc) and a $\beta$-D-galactopyranosyl (Gal) units, respectively, with more intense signals of Glc compared to those of Gal. The configuration of the anomeric positions of GluUA, Glc and Gal were determined as $\beta$ from the large coupling constant values between $\mathrm{H}-1$ and $\mathrm{H}-2$ (7.5-9.0 Hz) and their pyranose form was established based on their ${ }^{13} \mathrm{CNMR}$ data. The anomeric configuration of Ara(f) was assigned as $\alpha$ based on small coupling constant value between $\mathrm{H}-1$ and $\mathrm{H}-2(2.0 \mathrm{~Hz})$ and its furanose form was deduced from the ${ }^{13} \mathrm{CNMR}$ chemical shift values and down field position of the anomeric proton signal. ${ }^{5,17,18}$ The sugar pattern of $\mathbf{1}$ and $\mathbf{2}$ were established based on HMBC correlations. The observed correlations of 1 were GlcUAC-1 $\left(\delta_{c} 105.0\right) /$ TrilH-3, GlcC-1 $\left(\delta_{c} 104.0\right) / \mathrm{GlcUAH}-2\left(\delta_{\mathrm{H}} 3.70\right)$ and Ara(f)$\mathrm{C} 1\left(\delta_{\mathrm{c}} 111.1\right) / \mathrm{GlcUAH}-3\left(\delta_{\mathrm{H}} 3.70\right)$. The HMBC correlations of 2 were GlcUA C-1 $\left(\delta_{c} 105.7\right) /$ Tri2H-3, GalC-1 $\left(\delta_{c} 104.7\right) / G l c U A H-2\left(\delta_{\mathrm{H}} 3.77\right)$ and $\operatorname{Ara}(\mathrm{f}) \mathrm{C}-1(110.9) / \mathrm{GlcUAH}-3\left(\delta_{\mathrm{H}} 3.70\right)$. These data indicated that both saponins 1 and 2 contained a trisaccharide unit at C-3 position of the triterpene moiety, different only in the nature of the terminal sugar attached to the C-2 of the inner $\beta$-D-glucuronic acid unit, being glucose in $\mathbf{1}$ and galactose in $\mathbf{2}$. Therefore, the structures of the two sugar parts of 1 and $\mathbf{2}$ were elucidated as $\beta$-D-glucopyranosyl$(1 \rightarrow 2)$ - $[\alpha$-L-arabinofuranosyl- $(1 \rightarrow 3)]-\beta$-D-glucuronopyranosyl and $\beta$-D-galactopyranosyl- $(1 \rightarrow 2)$-[ $\alpha$-L-arabinofuranosyl- $(1 \rightarrow 3)]-\beta$ D-glucuronopyranosyl, respectively. The structures of the triaccharide moieties of $\mathbf{1}$ and $\mathbf{2}$ were supported by the mass data. The negative ESIMS/MS spectra of the molecular ions showed fragmentation pattern in agreement with the presence of a trisaccharide chain composed of one pentose, one hexose and one uronic acid units. The first ion at $m /$ $z 1041.5229$ displayed two intense peaks at $m / z 909.4804$ [(M-132)-H] and $571.4804[(\mathrm{M}-132-162-176)-\mathrm{H}]^{-}$while the second ion at $\mathrm{m} / z$ 1043.5415 showed two corresponding peaks at $\mathrm{m} / z 911.4930$ and $\mathrm{m} / \mathrm{z}$ 573.4166

From the aforementioned information, the structures of $\mathbf{1}$ and $\mathbf{2}$ were concluded as 3-O- $\beta$-D-glucopyranosyl- $(1 \rightarrow 2)$-[ $\alpha$-L-arabinofuranosyl$(1 \rightarrow 3)]-\beta$-D-glucuronopyranosyl22-O-angeloylA1-barrigenol and 3 - $O$ - $\beta$-D-galactopyranosyl- $(1 \rightarrow 2)$ - $[\alpha$-L-arabinofuranosyl- $(1 \rightarrow 3)]$ $\beta$-D-glucuronopyranosyl22-O-(2-methylbutyroyl)-A1barrigenol, respectively.

The $\alpha$-glucosidase inhibitory activity of the two saponin mixture was evaluated in vitro. ${ }^{19}$ The mixture proved to exhibit strong activity with $\mathrm{IC}_{50}$ value equals to $13.3 \pm 5.0 \mathrm{ppm}$ and $\mathrm{IC}_{90}$ value equals to $21.5 \pm 8.0$ ppm.

\section{EXPERIMENTAL}

\section{General}

Liquid chromatography-ion trap-top of flight mass spectrometry was performed using Shimadzu Liquid chromatography/ time-of-flight/ mass spectrometry (Shimadzu, Tokyo, Japan) with a Shim-pack XRODS column ( $50 \mathrm{~mm} \times 3.0 \mathrm{~mm} \times 2.2 \mu \mathrm{m}$ ). Solvent gradient consisted of $0.1 \%$ formic acid in $\mathrm{H}_{2} \mathrm{O}$ (A) and acetonitrile (B). Compounds were eluted into the ESI ion source at the flow rate of $0.4 \mathrm{ml} / \mathrm{min}$ with a step gradient of B in A: 10-85\% B (0-15 min), 85-10\% B (15-18 min), isocratic at $10 \% \mathrm{~B}(2 \mathrm{~min})$. Column was maintained at $40^{\otimes} \mathrm{C}$ during the run. Nitrogen gas was used as nebulizer and drying gas with the flow rate set at $1.5 \mathrm{~L} / \mathrm{min}$. The ESI source voltage was set at $4.5 \mathrm{kV}$ and the detector was set as $1.5 \mathrm{~V}$. Ionization was performed using a conventional ESI source in the negative ionization mode. Shimadzu's LC-MS solution software was used for data analysis. NMR experiments were performed on a Bruker Avance $700 \mathrm{MHz}$ spectrometer (Bruker BioSpin Corporation, Billerica, MA). ${ }^{1} \mathrm{H},{ }^{13} \mathrm{C}, \mathrm{HMQC}, \mathrm{HMBC}, \mathrm{COSY}$ and TOCSY NMR spectra were acquired in $\mathrm{CD}_{3} \mathrm{OD}$ at $700 \mathrm{MHz}$ for proton and $175 \mathrm{MHz}$ for ${ }^{13} \mathrm{CNMR}$. Chemical shifts are given as $\delta$ values with TMS as internal standard. Optical rotations were measured with jasco p-2000 polarimeter. Preparative HPLC was carried out on Interchim4100 (Montlucon, France) (column, RP C-18 HQ; solvent system, $\mathrm{CH}_{3} \mathrm{CN}-\mathrm{H}_{2} \mathrm{O}$ (33:67-70:30); Flow rate $20 \mathrm{ml} / \mathrm{min}$; Detection, $\mathrm{UV}, 205 \mathrm{~nm}$; temperature, $\left.35^{\circ} \mathrm{C}\right)$.

\section{Plant material}

$H$. pendula seeds were collected from the zoological garden in Giza, Egypt in September 2014. Plant identification was confirmed by Mrs. T. Labib, head specialist for plant identification in El-Orman public garden, Giza, Egypt. A Voucher specimen was deposited in the Herbarium of NRC (CAIRC).

\section{Extraction and isolation}

Air-dried seeds of $H$. pendula (100 g) were defatted with $n$-hexane then extracted with $\mathrm{MeOH}$ until exhaustion. The combined $\mathrm{MeOH}$ extract was evaporated under vacuum to dryness. The residue ( $4.5 \mathrm{~g})$ was suspended in water and partitioned with EtOAc $(5 \times 100 \mathrm{ml})$ then with water saturated $n-\mathrm{BuOH}(5 \times 100 \mathrm{ml})$. Each combined fraction was individually evaporated under reduced pressure to yield $1.5 \mathrm{~g}$ EtOAc fraction and $2.1 \mathrm{~g} n-\mathrm{BuOH}$ fraction. The $n-\mathrm{BuOH}$ fraction was dissolved in $\mathrm{H}_{2} \mathrm{O}(0.002)$ and the $\mathrm{H}_{2} \mathrm{O}$ solution was passed through a column chromatography packed with 100 g Diaion HP-20 polymer gel (Mitsubishi). After washing the column with distilled water, elution was carried out with $25 \%, 50 \%, 75 \%$ aqueous $\mathrm{MeOH}$ and finally with $100 \% \mathrm{MeOH}$. The collected fractions were examined by silica gel TLC (Merck) using solvent systems $n$ - $\mathrm{BuOH}-\mathrm{EtOH}-\mathrm{NH}_{4} \mathrm{OH}$ (7: 2: 5) and $\mathrm{CHCl}_{3}-\mathrm{MeOH}-\mathrm{H}_{2} \mathrm{O}$ (60: $30: 5$ ) then visualized by spraying with $20 \%$ sulphuric acid in $\mathrm{MeOH}$ followed by heating at $110^{\circ} \mathrm{C}$. Based on TLC analysis, similar fractions were then combined. Fractions eluted with $75 \%$ and $100 \% \mathrm{MeOH}$ were found similar and contained saponin constituents. The combined saponin fraction $(1.35 \mathrm{~g})$ was applied on a column chromatography packed with silica gel $(60 \mathrm{~g})$ and eluted with EtOAc $-\mathrm{MeOH}-\mathrm{H}_{2} \mathrm{O}$ with increasing polarity (30:2:1 - 5:2:1). A total of 50 fractions $50 \mathrm{ml}$ each were collected. Similar fractions were combined after TLC analysis to give eight sub-fractions (A-H). The sub-fraction E $(80 \mathrm{mg})$ eluted with EtOAc-MeOH- $\mathrm{H}_{2} \mathrm{O}$ (15:2:1) was subjected to repeated HPLC to afford an inseparable mixture of $\mathbf{1}$ and $\mathbf{2}$ in the ratio 2:1.

\section{Saponin 1}

HR-ESI-MS m/z $1041.5229\left[\mathrm{C}_{52} \mathrm{H}_{82} \mathrm{O}_{21}-\mathrm{H}\right]$; , calculated 1041.5276; ${ }^{1} \mathrm{H}$ and ${ }^{13} \mathrm{CNMR}$ (Table 1).

\section{Saponin 2}

HR-ESI-MS m/z $1043.5415\left[\mathrm{C}_{52} \mathrm{H}_{84} \mathrm{O}_{21}-\mathrm{H}\right]$; , calculated 1043.5441; ${ }^{1} \mathrm{H}$ and ${ }^{13} \mathrm{CNMR}$ (Table 1). 


\section{Acid hydrolysis}

The mixture of 1 and $2(5 \mathrm{mg})$ in $1.5 \mathrm{~N} \mathrm{HCl}(5 \mathrm{ml})$ was heated at $100^{\circ} \mathrm{C}$ for $4 \mathrm{~h}$. After cooling, the aqueous layer was extracted with $\mathrm{CH}_{2} \mathrm{Cl}_{2}$ then neutralized by repeated addition of $\mathrm{MeOH}$ followed by evaporation. The sugars obtained were detected against authentic samples by TLC conducted on HPTLC using solvent system 1-propanol-EtOAc- $\mathrm{H}_{2} \mathrm{O}$ $(4.0,0.5,0.5)$. The chromatogram was visualized by spraying with aniline hydrogen phthalate reagent and heating at $110^{\circ} \mathrm{C}$ till the colour of the spots appeared. D-Glucuronic acid, L-arabinose, D-glucose and $\mathrm{D}$-galactose were detected. The hydrolysis process was repeated using $40 \mathrm{mg}$ of $\mathbf{1}$ and $\mathbf{2}$ and the obtained sugars were separated by preparative TLC using the solvent system mentioned above. The optical rotations of the isolated sugars were measured and confirmed by comparison with the literature values.

\section{REFERENCES}

1. Mabberley DI. The plant-book: A portable dictionary of vascular plants, 2 nd ed. Cambridge University Press, Cambridge; 1997.

2. Voutquenne L, Lavaud C, Massiot G, Delaude C. Saponins from Harpullia cupanioides. Phytochemistry. 1998;49:2081-5.

3. Voutquenne L, Kokougan C, Lavaud C, Pouny I, Litaudon M. Triterpenoid saponins and acylated prosapogenins from Harpullia austro-caledonica. Phytochemistry. 2002;59:825-32.

4. Voutquenne L, Guinot P, Froissard C, Thoison O, Litaudon M, Lavaud C. Haemolytic acylated triterpenoidsaponins from Harpullia austro-caledonica. Phytochemistry. 2005;66:825-35.

5. Ghaly NS, Nabil M, Grace MH, Melek FR. Pendulaoside A and B. Two acylated triterpenoid saponins from Harpullia pendula seed extract. Phytochemistry. 2017;21:278-81.

6. Bharathimatha C, Doraiswamy S, Rabindran R, Velazhahan R. Inhibition of fungal plant pathogens by seed proteins of Harpullia cupanioides (Roxb). Acta Phytopathol Entomol Hung. 2002;37:75-82.
7. Devi PR, Doraiswamy S, Sevugapperumal N, Mathiyazhagan S. Antiviral action of harpullia cupanioides and Mirabilisjalapa against tomato spotted Wilt virus (TSWV) infecting tomato. Arch. Phytopathol Plant Protect. 2004;37:245-59.

8. Gowri H, Vasantha K. Solvent based effectiveness of antibacterial and phytochemical derivatized from the seeds of Harpullia arborea (Blanco) Radlk. (Sapindaceae). J Appl Sci Environ Manage. 2009;3:99-101.

9. Abdel-Gawad MM, El-Sayed MM, El-Nahas HA, Abdel-Hameed ES. Laboratory evaluation of the molluscicidal, miracidicidal and cercaricidal properties of two Egyptian plants. Bull Pharm Sci. 2004;27:331-9.

10. Khong PW, Keith GL. Chemical constituents of Harpullia pendula. Aust J Chem. 1976;29:1351-64

11. Cherry RF, Khong PW, Lewis KG. Chemical constituents of Harpullia pendula II. Further constituents of the bark and leaves. Aust J Chem. 1977;30:1397-400.

12. El-Gohary HMA. Phytochemical and biological study of seeds of Harpullia pendula planch. and Harpullia cupanioides Roxb. cultivated in Egypt. Bull Fac Pharm Cairo Univ. 2004;42(2):95-104.

13. El Sayed NH, El Ansari MA, Shalaby AM, Mabry TJ. Phenolics and flavonoids of the pericarp of Harpullia pendula. Rev Latinoamer Quim. 1988;19(2):66.

14. Abdelkader MSA, Rateb ME, Mohamed GA, Jaspars M. Harpulliasides A and B: Two new benzeneacetic acid derivatives from Harpullia pendula. Phytochemistry Letters. 2016;15:131-5.

15. Ohtsuki T, Miyagwa T, Koyano T, Kowithayakorn T, Kawahara N, Goda Y, et al. Acylated triterpenoid saponins from Schimanoronhae and their growth inhibitory activity. J Nat Prod. 2008;71:918-23.

16. Zhang XF, Han YY, Bao GH, Ling TJ, Zhang L, Gao LP, et al. A new saponin from Tea seed Pomace (Camellia oleifera Abel) and its protective effect on PC12 cells. Molecules. 2012;17:11721-8.

17. Agrawal PK. NMR spectroscopy in the structural elucidation of oligosaccharides and glycosides. Phytochemistry. 1992;31(10):3307-30.

18. Melek FR, Miyase T, Abdel-Khalik SM, Hetta MH, Mahmoud II. Triterpenoid saponins from Oreopanax guatemalensis. Phytochemistry. 2002;60:185-95.

19. Xiao Z, Storms R, Tsang A. A quantitative starch-iodine method for measuring alpha-amylase and glucosidase activities. Analytical Biochemistry. 2006;351(1):146-8.

\section{GRAPHICAL ABSTRACT}

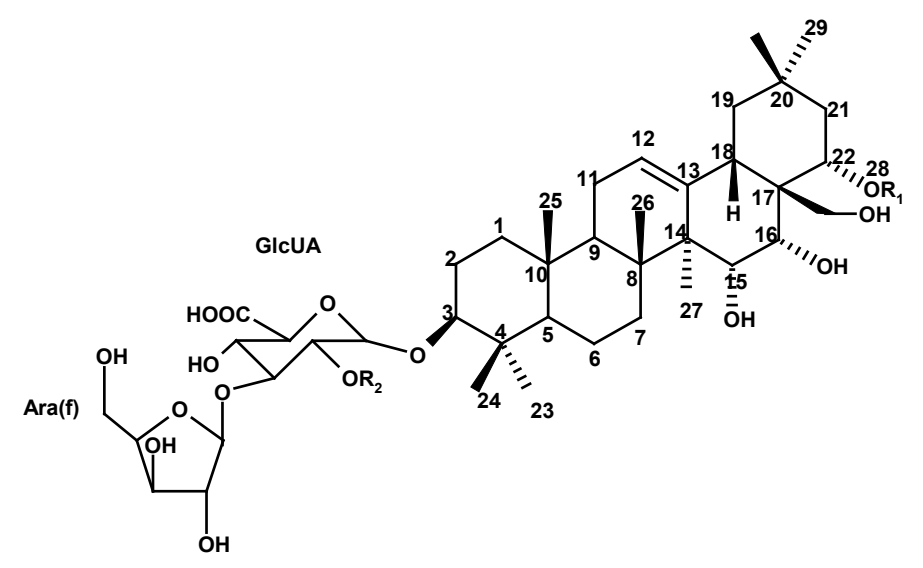

$\mathbf{R}_{1}$

$\mathbf{R}_{2}$

1<smiles>C/C=C(/C)C(C)=O</smiles><smiles>CC(O)C(O)C(O)C(O)C(C)O</smiles>

2<smiles>CCC(C)C(C)=O</smiles> 


\section{SUMMARY}

Two new triterpenoid saponins named pendulaoside $C$ and $D$, were obtained from Harpullia pendula seed methanolic extract. Their structures were established by spectral and chemical means.

\section{ABOUT AUTHORS}

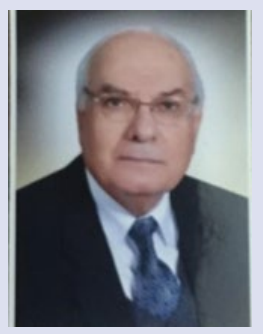

\section{Prof. Dr. Farouk Rasmy Melek}

Born in June 1944. Graduated from faculty of science, Cairo University in May 1963. Joined National Research Centre in May 1964. Received master degree in 1978 and PhD degree in 1978. Appointed a professor in 1990. Published more than 70 publications in national and international journals. Participated in several research projects as a P.I. or a partner.

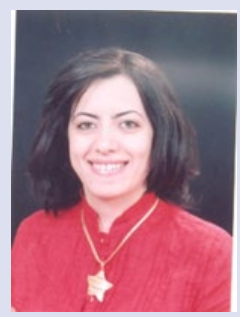

\section{Dr. Marian Nabil Fekry}

Current Position: Researcher of Chemistry of natural Compounds (since 2012), Chemistry of Natural Compounds Department, Pharmaceutical and Drug Industries Research Division, National Research Centre.

\section{Research Interest:}

Natural Products Chemistry: Separation and purification of organic compounds using chromatographic techniques.

Advanced Spectroscopic Techniques for Organic Structures Identification: Identification of organic compounds using advanced NMR techniques (COSY, NOESY, HMBC, HMOC).

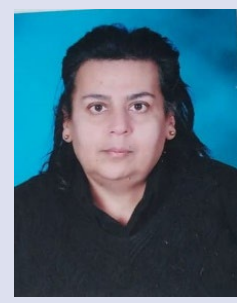

\section{Asst. Prof. Neveen Sabry Ghaly}

Associate professor in 2011. Published 15 publications in national and international journals. Participated in several research projects.

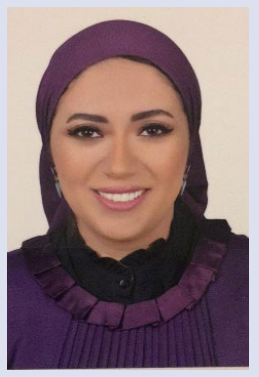

\section{Dr. Iman Kassem}

Iman Kassem is a researcher in National Research Centre, Giza, Egypt and part-time lecturer in faculty of Pharmacy, Nahda University, Beni-Suef, Egypt. She received her BSc from faculty of Pharmacy, Ain Shams University. She also received her M.Sc. and Ph.D. from faculty of Pharmacy, Cairo University. She lives in Egypt.

Cite this article: Nabil M, Ghaly NS, Kassem IAA, Grace MH, Melek FR. Two Triterpenoid Saponins with $\alpha$-glucosidase Inhibitory Activity from Harpullia pendula Seed Extract. Pharmacog J. 2019;11(6)Suppl:1386-90. 